\title{
Música e Dramaturgia: Um Estudo em Forma Sonata
}

\section{Claudiney Rodrigues Carrasco}

Muito se discute a respeito da música enquanto linguagem. No decorrer deste século, com o avanço e aparelhamento cada vez maior da Semiótica, muitos estudiosos se aventuraram no terreno da música, tentando estabelecer os paråmetros que permitissem um entendimento da linguagem musical sob o ponto de vista da Semiótica. Contudo, se para outras linguagens o aparato metodológico da Semiótica foi de grande eficiência, aplicado à linguagem musical nunca chegou a conclusões definitivas, que fossem aceitas consensualmente pelos profissionais de ambas as áreas.

São muitas as questoes que ainda estào para serem respondidas: a Música é, de fato, uma linguagem? Existe um código ou códigos musicais? Como se dá a relaçào Significante/Significado em música?

Não me proponho neste texto oferecer respostas a estas perguntas, muito menos pretendo tomar como ponto de partida o referencial metodológico da Semiótica, que não é a minha especialidade. Proponho-me apenas indicar um outro caminho de análise, sob o ponto de vista da ciência da Dramaturgia e aplicá-lo especificamente à forma sonata, por tratar-se de uma forma extremamente clara, onde a direcionalidade e o princípio narrativo do sistema tonal são levados às últimas conseqüências.

* Trabalho apresentado no Curso de Pós-Gracluaçào da ECA-USP, na disciplina "Música e Linguagem - a Evolução do Sentido", ministrado pelo Prof. Dr. Silvio Crespo. 
Para tanto, parto da premissa de que a musica pode ser tratada como linguagem e assim vou me referir a ela no decorrer deste trabalho, sem levar em conta a polêmica que o uso do termo possa provocar. Paralelamente, aceito também a premissa de que o Sistema Tonal seja um código a partir do qual se organiza o discurso tonal. Esclarecidos esses pontos, podemos dar início à apresentação do trabalho propriamente dito.

\section{I - Primeiro Tema: O Sistema Tonal e a Forma Sonata}

A forma sonata é o grau máximo de desenvolvimento de um processo que começa na Idade Média, por volta do século IX. É nesse momento que a música ocidental descobre uma de suas principais especificidades: a polifonia. A partir de então, deixa-se de cantar a uma única voz e passa-se a sobrepor, inicialmente, uma segunda voz, posteriormente uma terceira, uma quarta e, em alguns casos, mais vozes.

Essa polifonia vai se tornando cada vez mais complexa. Contudo, durante muito tempo se pensou a música linearmente, ou seja, nos primórdios da polifonia os compositores sobrepunham a uma voz já existente, normalmente um canto gregoriano, uma segunda voz e a preocupação era sempre maior com o sentido horizontal dessas vozes. Os conjuntos de notas simultâneas (ou sentido vertical) eram apenas fruto do encontro dessas vozes e não de um princípio organizacional que reconhecesse unidades sonioras verticais, os acordes.

O conceito de acorde só vai surgir mais tarde, na Renascença, por volta do século $\mathrm{XV}$, quando começa a se estabelecer uma padronização desses encontros de vozes. A sobreposição de três sons por ordem de terças (posição fundamental) e as duas outras combinações possíveis desses mesmos sons (inversões) passa a ser visto não mais como o resultado do encontro de vozes, mas como uma unidade, um signo que é incorporado ao léxico musical do período. 
Muitos historiadores fazem um paralelo entre o surgimento desse sentido vertical na música com o surgimento da perspectiva na pintura. De fato, o acorde é o signo musical que objetiva o sentido de profundidade, espacialização do som. É o que permite o desenvolvimento do trabalho musical em planos distintos, porém, simultâneos.

$\mathrm{O}$ acorde, enquanto conceito, foi de fundamental importância para o desenvolvimento da música no sentido do estabelecimento de um código, mas o processo não chega à sua conclusão ainda nesse momento. Muitos dos procedimentos musicais da antiga tradição polifônica ainda estão presentes. Vão ser necessários mais de dois séculos de experimentação com o acorde para que surja uma nova mudança significativa na música. Durante esses dois séculos vão se abandonando alguns procedimentos que a música ocidental herdou de sua origem, tais como o movimento melódico conhecido por "Cadência de Landino" ou a dupla sensível, característica de periodos anteriores.

Desenvolvem-se também algumas combinações de acordes que passam a ser usadas com muita freqüência. Embora as progressōes harmônicas sejam ainda muito experimentais nessa época, já podemos encontrar com freqüência alguns dos movimentos harmônicos que mais tarde vão ser característicos do sistema tonal, como é o caso da progressãa entre acordes cujas fundamentais se encontram a uma distância de quarta ou quinta justa, que mais tarde, no sistema tonal, vão se tornar o centro da polaridade do sistema: a relação Dominante/Tônica e Subdominante/Tônica. Contudo, há aqui ainda uma predominância muito grande dos acordes que, mais tarde, serão conhecidos como Funções Secundárias, ou progressões de acordes cujas fundamentais estão em relação de terça ou segunda e movimentos cadenciais diversos, pois ainda não existe uma noção musical definida de "Centro Tonal".

Esse período que vai do século XV ao século XVI pode ser definido como Período Pré-Tonal, pois nele já estão presentes todos os elementos que formam o léxico tonal, sem no entanto 
ter-se desenvolvido o princípio hierárquico funcional, que é o que vai permitir a consolidação do sistema, enquanto código, para a linguagem musical.

Outra reforma importantíssima para a consolidação do sistema tonal foi a adoção, no início do século XVIII, do sistema de afinação temperado, que divide a oitava em doze semitons de igual tamanho, permitindo que se caminhe com total liberdade de uma tonalidade para outra, ampliando os limites da modulação, que é um dos pilares do discurso tonal.

Por volta do início do século XVIII, o novo sistema tonal já está consolidado. Nessa época é escrito o primeiro trabalho teórico sobre o sistema tonal: o Tratado de Harmonia de Rameau, curiosamente publicado no mesmo ano em que J. S. Bach escreve o primeiro volume de O Cravo Bem Temperado que, paralelamente ao trabalho teórico de Rameau, apresenta a realização prática dos recursos e possibilidades do novo sistema.

Nesse momento, o princípio hierárquico/funcional da tonalidade já está totalmente assimilado a nivel da frase musical. Os movimentos cadenciais, rítmicos e rítmico-harmōnicos também são hierarquizados. O discurso musical torna-se cada vez mais lógico, direcional e gradualmente conquista a sua independẻncia da palavra, do canto, que havia sido seu fio-condutor desde a Idade Média. É aí, a partir do barroco, que podemos começar a observar aquilo que hoje conhecemos por "música pura" ou "absoluta", ou seja, o discurso musical por si só, sem texto. A partir daí a música caminha em direção ao seu estabelecimento como linguagem propriamente dita e organiza o seu discurso no sentido de bastar-se a si mesma.

Inicialmente, essa organização dá-se ao nivel da frase musical. A lógica e a direcionalidade manifestam-se no tipo de organização do material sonoro, que passa a vigorar a partir de então. 0 discurso musical inicia-se com a apresentaçào de uma idéia, ou Motivo, em termos técnicos e através das transformações, repetições, contraposições desse motivo/idéia desenvolve-se a frase musical, com começo, meio e fim. 
Outro passo importante dado no período barroco no sentido da consolidação da lógica do discurso musical foi o entendimento da função harmônica enquanto entidade abstrata. $\mathrm{O}$ acorde passa a ser nào mais uma unidade absoluta, mas uma função dentro de um conjunto de relações harmônicas ditado pela ordem interna da tonalidade. Os acordes são divididos em grupos: Funçôes Principais e Funções Secundárias. Ocorre uma sistematização das polaridades tonais: Tónica, Subdominante e Dominante. Um mesmo acorde assume funções diferentes para tonalidades diferentes.

Organiza-se uma sintaxe para o discurso musical. A partir de então, não se pensa mais a progressão harmónica pela busca de contraste entre um determinado acorde e seu subseqüente, mas sim pela relação funcional desses acordes. Por trás da prática musical passa a haver um princípio abstrato, porém audível. Se o compositor escreve música por relações funcionais, o ouvinte também ouve as mesmas relaçòes, pois a polaridade funcional é perfeitamente clara para um ouvido habituado à linguagem tonal.

No que diz respeito ao aspecto formal, a música do barroco é essencialmente monotemática. $O$ discurso é construido a partir das transformaçòes de um único tema.

Apenas no periodo subseqüente, o Classicismo, na virada dos séculos XVIII e XIX, essa sintaxe, a abstraçăo funcional, é levada ao nível da forma. É o momento em que o discurso tonal atinge o seu ponto culminante e, por conseqüência, é também o momento em que a música atinge um grau de complexidade tal em sua organização, que muito a aproxima da linguagem verbal.

No Classicismo, aquela abstraçào funcional, que já está presente no Barroco ao nível da frase, é levada para toda a estrutura formal da música. Isso pode ser verificado na forma mais característica do Classicismo: a forma sonata.

A sonata é uma forma bitemática, que pode ser resumida no seguinte esquema: 
SLÇĀO: INTROD. / EXPOSIÇ. / DESENVOI.V. / RLAXIPOS. / CODA

(Opcional)

THMA: Livre $/ 1^{\circ} \mathrm{T} 2^{\circ} T^{*} /$ Fragmentaçào / $1^{\circ} \mathrm{T} 2^{\circ} \mathrm{T} /$ Livre

${ }^{\circ} \mathbf{T} 2^{\circ} \mathrm{T}$

TONAL: Tônica / T.D.** / Modulações / T. T. / T.

Instabilidade

(* 1 "T. = Primeiro Tema;

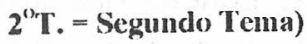

(** T. = Tönica;

D. = Dominante)

Em oposiçào às formas monotemáticas do Barroco, a sonata introduz um segundo tema e, através do confronto entre os dois materiais temáticos, desenvolve não apenas um discurso organizado, mas um verdadeiro Drama. Na audiçào de uma forma sonata, o ouvinte é conduzido por uma narrativa clara e concisa, sem que seja necessária a intervençào da palavra.

\section{II - Segundo Tema: Dramaturgia e Música - A Forma Sonata}

Quando dissemos anteriormente que na organizaçào da forma sonata ocorre um drama, nào o fizemos apenas com um sentido metafórico. De fato, um verdadeiro paralelo pode ser traçado entre a estrutura formal da sonata e os principios que regem a organização da obra dramática. Para iniciar esse paralelo, vamos nos remeter à origem da ciência da dramaturgia, ou seja, a Arte Poética de Aristóteles, onde encontramos a definiçào dos diversos gêneros poéticos como modos de imitar a realidade:

"Propomo-nos a tratar da produçao poética em si mesma e de seus diversos géneros, dizer qual a funçào de cada un deles, como se deve construir a fábula, no intuito de obter o belo poético; qual o número e a natureza de suas diversas partes, e falar igualmente dos demais assuntos relativos a esta produçāo... 
... A epopéia e a poesia trágica e tambén a comédia, a poesia ditirâmbica, a maior parte da aulética e da citarística consideradas em geral, todas se enquadram nas artes de imitaçào.

... Nas artes acima indicadas a imitaçào é produzida por meio do ritmo, da flinguagem e da harmonia...

... Utilizam a harmonia e o ritmo só a aulética e a citarística...

Como podemos notar, Aristóteles faz uma referência à arte musical (aulética e citarística) enquanto um gênero das artes imitativas. Mas de onde vem essa imitaçào? Qual é a açâo imitada pela música? Se estamos considerando a música uma linguagem, o paralelo mais imediato que podemos estabelecer é com a linugagem verbal, ponto de partida de todas as linguagens. Por esse ponto de vista poderíamos encarar a música como uma abstração da linguagem verbal. Este paralelo é possível a partir do momento em que observamos que, através do tempo, nas mais diversas culturas, encontramos uma quantidade muito maior de música vocal do que puramente instrumental. A música vocal, em sua grande maioria, possui um texto, sobre o qual o discurso musical é construído. Através dessa observação pode-se inferir, embora não seja possível prová-lo, que a música tem uma origem próxima à da fala. Cantar ou se expressar musicalmente pode ser considerado um modo diferente de falar. Sob esta óptica, a música pode ser considerada uma abstraçào ou imitação da fala.

Tendo definido a poesia como imitaçào, Aristóteles disserta sobre a origem dos diversos gèneros poéticos. Na verdade, a teoria dos gêneros tem sua origem não em Aristóteles, mas no terceiro livro da Répública de Platào, onde Sócrates apresenta os três tipos de obras poéticas:

"O primeiro é inteiramente imitaçào. O poeta como que desaparece, deixando falar, en vez dele, personagens. Isso ocorre na tragédia e na comédia. O segundo tipo é um simples relato do poeta... O terceiro tipo, enfim, une ambas as coisas; tu o encontras nas epopéias."

Já em Aristóteles, vamos encontrar a seguinte definição: 
"Com efeito, é possivel imitar os mesmos objetos nas mesmas situações, numa simples narrativa, ou pela introduçào de um terceiro, como faz Homero, ou insinuando-se a própria pessoa sem que intervenha outra personagem, ou ainda apresentando a imitação com a ajuda de personagens que vemos agir e executar elas próprias."

A respeito desta passagem, Anatol Rosenfeld faz o seguinte comentário em seu livro O Teatro Épico:

"Essencialmente, Aristóteles parece referir-se, neste trecho, apenas aos gèneros épico, isto é, narrativo, e dramático. No entanto, diferencia duas maneiras de narrar, uma em que há a introdução de um terceiro e outra em que se insinua a própria pessoa (do autor), sem que intervenha outra personagem. Esta última maneira parece aproximar-se do que hoje chamaríamos de poesia lírica... Quanto à forma dramática, é definida como aquela em que a imitaçào ocorre com a ajuda de personagens que, eles mesmos, agem ou executam açōes." (4)

Assim, chegamos à definiçào moderna dos très gêneros: o lírico, expressão do "eu" do poeta, de sua visào pessoal sobre determinado assunto. O épico, que é o gênero da narrativa propriamente dita, onde o poeta conta a açào sem a sua participação. E, finalmente, o gènero dramático, onde através de personagens a ação é representada. Assim, o gênero dramático só pode existir a partir do momento em que exista o diálogo. Um monólogo está sempre mais próximo da expressão do "eu" lírico, dado que não existe o conflito inerente à interlocução.

É neste sentido que a forma sonata pode ser dramática, pois é através do confronto entre os dois temas que se desenvolve a peça musical. Enquanto música "pura", a sonata nao necessita de programa literário, que vai se tornar um componente muito comum no período Romântico (ver "Sinfonia Fantástica" de Berlioz) e que exerce uma função épica em relação à música, a partir do momento em que a descreve, trazendo-a do plano puramente musical ao literário. 
Também derivada da Poética de Aristóteles é a teoria das três unidades dramáticas:

- Unidade de Tempo;

- Unidade de Espaço;

- Unidade de Ação.

As duas primeiras, Tempo e Espaço, não apresentam muitos problemas: um drama deve ocorrer em um determinado lugar e em uma determinada época ou período de tempo. Em relação a estas duas unidades podemos estabelecer um paralelo com a música tonal: uma música deve ser construída sobre uma determinada tonalidade, da mesma maneira que a ação dramática ocorre em um lugar determinado. A tonalidade é o espaço de ação para a música tonal. Também toda a organização temporal da música tonal é dada pelo sistema métrico do compasso. Da mesma maneira que as unidades de tempo e espaço são estabelecidas no início da obra dramática, ao se determinar onde e quando vai ocorrer aquela ação que será representada, também os seus equivalentes musicais são determinados no início da partitura, na armadura da clave.

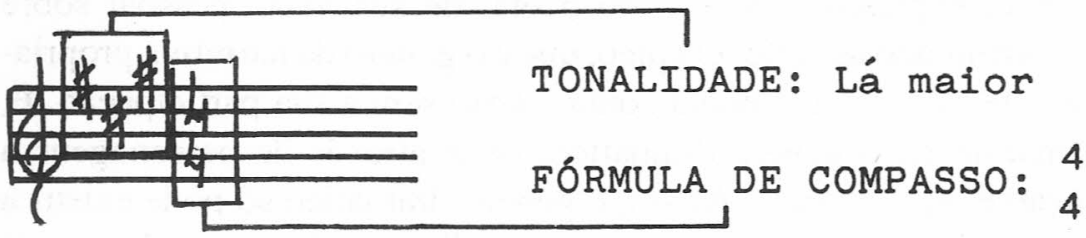

Mais complexa é a definição de unidade de ação. Sobre ela, Aristóteles diz o seguinte:

"O que dả unidade à fábula não é, como pensam alguns, apenas a presença de uma personagem principal; no decurso de uma existência produzem-se em quantidade infinita muitos acontecimentos, que não constituem uma unidade. Também muitas ações, pelo fato de serem executadas por um só agente, não criam a unidade... Mas Homero, ao compor a Odisséia, não deu acolhida nela a todos os acontecimentos da vida de Ulisses... Em torno de uma ação única, agrupou ele todos os elementos da Odisséia e outro tanto o fez para a Ilíada." (5) 
A exposição de Aristóteles pode parecer um pouco ampla. O que significa, de fato, ater-se a uma açào?

Essa conceituação de Aristóteles vai ser ampliada mais tarde por Hegel, que aborda a unidade de ação sob o ponto de vista do conflito, tal como encontramos em Introdução à Dramaturgia da Professora Renata Pallottini:

"A finalidade de uma ação só é dramática se produzir outros interesses e paixões opostas.

Está aí claramente exposto o princípio do conflito, inerente à filosofia toda de Hegel: uma ação, desencadeada por uma vontade, que tem em mira um determinado objetivo, colide com ... vontades opostas. Esta colisão é o conflito. E desta colisào algo nascerá." (6)

E ainda:

"A unidade de ação se encontra na persecussão e realização de um fim determinado através de um conjunto de conflitos; a verdadeira unidade, no entanto, só se realiza no movimento total (que inclui todas as vontades e todas as colisòes).

Diz ele (Hegel), que toda ação deve ter um fim determinado ... O conjunto, a constelação dessas açòes (e vontades), caminhando para um fim (desenlace), é o que caracteriza a unidade de ação." (7)

Se a unidade de ação se confunde com o conflito, ou conjunto de conflitos, como afirma Hegel, como podemos traçar um paralelo com o drama musical da forma sonata? Como podemos aplicar o conceito de conflito à linguagem musical?

Ao que parece, na linguagem musical, o conflito pode ocorrer em diversos níveis. No nível da forma o principal conflito que encontramos na sonata é aquele que ocorre entre o primeiro e o segundo grupos temáticos. Ao iniciar-se a exposição de uma sonata, é-nos apresentada uma idéia completa, composta por afirmações e interrogações, frases e períodos, e que possui um determinado caráter que é dado pela atividade rítmica interna, progressòes harmônicas, texturas, dinàmicas, linha melódica e uma infinidade de outros fatores musicais. Isto é o primeiro grupo temático, que vai ser conflitado a seguir com seu opositor, o segundo grupo temático, que possui outras características, mas 
também é uma idéia completa. Podemos dizer que, assim como no drama, o primeiro grupo temático possui uma vontade que vai colidir com a vontade oposta do segundo. Este confronto temático capta a atenção do ouvinte e desperta nele aquilo que poderíamos definir (sem muito rigor) por "curiosidade narrativa", ou seja, o interesse de acompanhar a narrativa tanto por seu desenlace como pelo desenvolvimento da narrativa por si mesma. Vamos encontrar uma referência a isto em Uma Anatomia do Drama de Martin Esslin:

"Para usarmos termos mais simples e correntes, a tarefa básica de qualquer pessoa preocupada em apresentar qualquer espécie de drama a uma platéia consiste em captar a atenção desta e prendè-la pelo tempo que for necessário...

... Assim sendo, a criação do interesse e do 'suspense' (em seu sentido mais lato) está por trás de toda construção dramática. Expectativas precisam ser despertadas, mas nunca satisfeitas antes do momento final em que cai o pano; a ação precisa parecer estar, a cada momento, chegando mais perto de seu objetivo, porém sem atingi-lo de forma completa antes do final."

Segundo Esslin, esse "suspense" pode ocorrer de diversas maneiras:

"Existe um sem-número de espécies de "suspense": este pode estar em uma pergunta como: 'E agora, o que vai acontecer?', mas igualmente pode estar contido na pergunta: Éu sei o que vai acontecer, mas como será que vai acontecer?, ou até mesmo: 'Eu sei o que vai acontecer, mas como será que $\mathrm{X}$ vai reagir? Ou ele poderá ser também de outro tipo completamente diferente, tal como: ‘O que será que estou vendo acontecer?', ou: Esses acontecimentos parecem formar um esquema qualquer, mas que tipo de esquema será?' Uma coisa, apenas, é certa: alguma espécie de indagação básica tem de emergir logo no início de qualquer forma dramática, de modo que o público possa, por assim dizer, estabelecer quais serão seus principais elementos de "suspense'."

Cada uma dessas maneiras de criar o "suspense" poderia ser aplicada a diferentes formas musicais. Em se tratando da forma 
sonata, a mais adequada parece ser a segunda: "Eu sei o que vai acontecer, mas como será que vai acontecer?" De certo modo, ocorre na audição de uma forma sonata um processo parecido com aquele que ocorre quando assistimos a um seriado de televisão: nós sabemos de antemão que o herói será ameaçado por diversos perigos e que conseguirá se safar de todos eles ileso, porém, assistimos apenas pelo prazer de ver como ocorrerá tudo isso. Em Twilight Zone - Combinatórias Narrativas e Intertextualidade do Prof. Heitor Capuzzo, encontramos a seguinte passagem sobre esse tipo de estrutura narrativa:

"Percebe-se, ainda hoje, que a repetição estrutural reforça a familiaridade para com os espectadores. A possibilidade de acompanhar um mesmo personagem em aventuras estruturalmente repetitivas, onde alguns detalhes são alterados, parece remeter 0 espectador a apreciar as variações possiveis de uma mesma fórmula. Com o tempo o espectador está familiarizado com a linguagem (fílmica) propriamente dita, sabendo que o ápice ficará para o próximo capítulo, mas que, após seu herói passar por tantos apuros, o 'happy-end " confortará a todos." (10)

Tal como foi descrito acima em relação ao seriado, na forma sonata os elementos narrativos são estabelecidos a priori. $\mathrm{O}$ ouvinte sabe que serão apresentados dois grupos temáticos contrastantes, que esse material será conflitado e modificado no desenvolvimento e, finalmente, haverá uma reexposição desse material com algumas modificações. Portanto, a nossa curiosidade não é voltada para "o quê" o compositor vai fazer com o material temático, mas para "como" ele vai trabalhá-lo dentro dessa estrutura.

Esse envolvimento do espectador ou ouvinte não ocorre apenas pela organização da forma, ou macroestrutura da narrativa:

"Acontece, porém, que a capacidade humana para manter a atenção em alguma coisa é relativamente curta. Um único elemento principal de "suspense" não é suficiente para prender a atenção da platéia através de toda a duração de uma peça... O componente 
principal de 'suspense', por assim dizer, leva o subsidiário na garupa."

Da mesma maneira que ocorre no drama, na forma sonata $e$, de certo modo, na música tonal como um todo, a atenção do ouvinte é sustentada não apenas pela organização dessa macroestrutura formal, mas também por elementos médio e microestruturais, ou subsidiários, como os denomina Esslin. Esses elementos podem ser encontrados nos diversos movimentos cadenciais, nas variações de andamento, na mudança de atividade rítmica (valores longos, valores curtos), nas articulações, dinâmicas, texturas e, especialmente, no jogo tonal das funções harmônicas, que ocorre tanto pela escolha dos graus dentro de um determinado campo, como pelas alterações de campo tonal proporcionadas pelas modulações, que também podem ser classificadas em principais e subsidiárias. Principais são aquelas modulaçōes que estão ligadas à estrutura formal, as que ocorrem entre uma seção e outra da peça. As subsidiárias seriam aquelas modulações que ocorrem internamente a uma seção, normalmente de curta duração, ou de passagem, no caminho de uma modulação principal e que normalmente funcionam como uma pequena fuga da tonalidade principal. É o caso, por exemplo, dos movimentos cadenciais sobre a dominante, ou subdominante, onde encontramos acordes que não pertencem à tonalidade propriamente dita, mas estão relacionados a ela, tais como as dominantes individuais.

Assim, poderíamos definir o processo de acompanhamento da narrativa musical pelo ouvinte como ocorrendo em dois níveis distintos e intercomunicantes: o primeiro estaria ligado à forma, às grandes seçōes da peça musical e poderia ser simbolizado por um arco, que vai do início ao fím da peça.

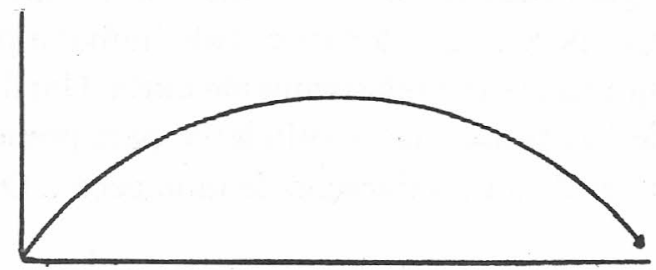


O segundo nível é o que faz com que a atenção do ouvinte seja requisitada continuamente no decorrer da narrativa musical e está ligado às pequenas estruturas. Este nível pode ser representado por pequenos arcos sobrepostos ao arco principal:

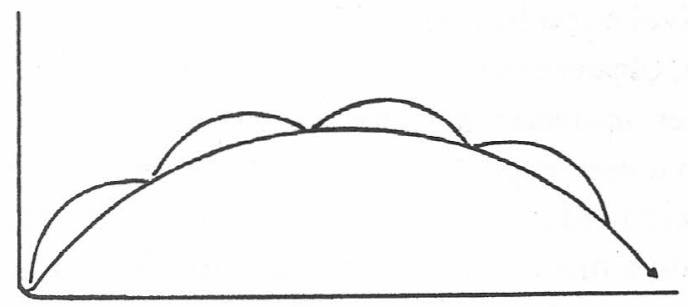

O signo musical não é passível de uma descrição objetiva pela linguagem verbal, ou seja, no que diz respeito ao plano semântico, não é possível transpor o signo musical para a linguagem verbal, a não ser pelo uso da própria linguagem técnica da música. Para esclarecer mais esta minha afirmação, lanço mão do seguinte exemplo: quando observamos um quadro, podemos dizer que se trata da imagem de uma mulher, em determinado lugar etc.. Ao assistirmos a um drama, podemos identificar personagens: um amante apaixonado, um vilão etc.. A linguagem musical não permite este tipo de descrição. Podemos nos referir apenas dentro dos limites estabelecidos pelo próprio código musical. No que diz respeito à música tonal, podemos dizer que uma determinada progressão partiu da tônica, caminhou pela subdominante, dominante e veio à sua conclusão novamente na tônica. $\mathrm{Na}$ verdade, quando dizemos isso, estamos de fato nos referindo a signos musicais dotados de valor semântico claro e preciso, mas apenas dentro da linguagem musical, pois esses termos descrevem relações precisas entre sons. A música é uma linguagem que trabalha com relações sonoras em seu estado puro, e é do resultado obtido pela justaposição (horizontal ou vertical) desses sons, que surge 0 signo musical.

Portrabalhar com relações básicas, a música é uma linguagem que poderia ser explicada parcialmente pela linguagem verbal, como um conjunto de relações sonoras em um vasto espectro que 
vai do grau máximo de repouso ao grau máximo de tensão. É através desse jogo entre tensão e repouso que ocorre a narrativa musical e todo esse processo que foi descrito acima, sobre como o ouvinte acompanha a narrativa musical, para que ela lhe seja compreensivel e inteligivel.

Assim, observamos que o conceito de conflito na obra musical pode ser aplicado a todos os níveis da linguagem e está relacionado a esse espectro que vai do repouso à tensão, desde o nível mais elementar da linguagem musical (alturas, valores, motivos etc.) até a macroestrutura formal como um todo.

Tendo-se estabelecido o conflito (ou conjunto de conflitos), é necessário que a narrativa se desenvolva em direção a seu desenlace. Na Poética de Aristóteles encontramos a definição de ação complexa, como aquela que alcança seu desenlace por meio de peripécias ou reconhecimentos. A respeito destes dois conceitos, Aristóteles diz o seguinte:

"A peripécia é a mudança da ação no sentido contrário ao que foi indicado e sempre, como dissemos, em conformidade com o verossímil e necessário... O reconhecimento, como o nome indica, faz passar da ignorância ao conhecimento, mudando a amizade em ódio ou inversamente, nas pessoas voltadas à felicidade ou ao infortúnio." (13)

Para que o conflito chegue ao seu desenlace, é necessário que esse conflito seja esgotado, explorado sob todos os seus aspectos. É nesse caminho que se encontram as peripécias e os reconhecimentos para o drama aristotélico. É nesse sentido, também, que o compositor trabalha a seção de desenvolvimento na forma sonata. No desenvolvimento, já não podemos falar em primeiro tema ou segundo tema, mas em material temático oriundo do primeiro e do segundo grupos, já que, normalmente, esse material temático aparece fragmentado nesta seção.

No desenvolvimento, os fragmentos do material temático são confrontados e transformados. Ocorre nele uma explicitação do conflito, ou conflitos, estabelecidos na exposição e, através dessa 
explicitação, ocorre também o esgotamento desses conflitos, que conduz, necessariamente, à resolução ou estabilidade.

Os recursos usados pelo compositor para atingir este objetivo são similares aos que o dramaturgo usá para conduzir ao desenlace. Peripécia e reconhecimento são, na verdade, apenas alguns dos recursos possiveis para que o dramaturgo introduza novas informações que vão alterar o perfil da curva dramática. De modo similar, o compositor transforma o material temático através de novas informações musicais, tais como: mudanças de modo (maior/menor), transformações rítmicas (aumentação/diminuição), inversão de direção (ascendente/descendente), comibinação de fragmentos dos dois temas, sobreposição etc., o que possibilita um número quase infinito de combinações sonoras daquele material.

Esse esgotamento do material temático promovido pelo desenvolvimento funciona como clímax da sonata e conduz ao desenlace, da mesma forma que as peripécias e reconhecimentos conduzem ao desenlace a tragédia grega. O desenlace é a parte da obra dramática onde o conflito é resolvido e retorna-se a uma situação de estabilidade, mesmo que essa nova estabilidade seja o infortúnio, como é o caso da tragédia grega. Na sonata, o desenlace corresponde à reexposição, onde os dois temas são reapresentados. Contudo, após terem passado pelo desenvolvimento, os dois grupos temáticos não podem ser reapresentados exatamente como o foram na exposição, pois isto seria um retorno ao conflito inicial e não um desenlace. Assim, o procedimento usual é o de reapresentar os dois temas com pequenas modificações. A mais comum dessas modificaçōes é a que diz respeito à tonalidade: a exposição é feita com o primeiro grupo temático na tonalidade principal e o segundo na tonalidade da dominante. $\mathrm{Na}$ reexposição os dois grupos temáticos são apresentados na tonalidade principal. Outras modificações usuais são as rearmonizações, mudança de textura, acompanhamento, ornamentação, entre outras, ou seja, pequenas mudanças que não chegam a descaracterizar o material temático, nem permitem que ele perca a sua individualidade. 
Com isso, nossos personagens chegam ao final, como em todo drama, modificados, pois a metamorfose através da ação é o objetivo da obra dramática. Quando vamos assistir a um espetáculo de cunho dramático, queremos ver uma transformação dos personagens provocada por aquela ação. Se ao final do espetáculo tudo permanecer inalterado, se não houver uma transformação provocada por aquele conjunto de conflitos, experimentamos uma sensação de insatisfação. Ai está embutida a idéia de "redenção", tal como aparece no conto de fadas, à qual o herói só chega pela metamorfose pessoal, obtida através do confonto com uma força muito maior qua a sua. Da mesma maneira, os dois temas em conflito na exposição da sonata sofrem a metamorfose do desenvolvimento e alcançam a reexposiçāo em um novo estado de equilíbrio.

Graças à sua estrutura dramática, podemos dizer que a forma sonata foi responsável por um momento muito especial da história da música ocidental. Nunca antes a música teve um grau tão grande de liberdade e independência enquanto linguagem. Tendo como referencial apenas a linguagem musical, a forma sonata basta-se a si mesma, assim como a obra dramática também só pode contar com os recursos inerentes à própria ação, como afirma Rosenfeld:

"Estando o 'autor' ausente, exige-se no drama o desenvolvimento autônomo dos acontecimentos, sem a intervençào de qualquer mediador, já que o autor confiou o desenrolar da ação a personagens colocados em determinada situação. $O$ começo da peça não pode ser arbitrário, como que recortado de uma parte qualquer do tecido denso dos eventos universais, todos eles entrelaçados, mas é determinado pelas exigências internas da ação apresentada. $\mathrm{E}$ a peça termina quando esta açào nitidamente definida chega ao fim. Concomitantemente impoe-se rigoroso encadeamento causal, cada cena sendo a causa da próxima e esta sendo o efeito da anterior..."

É assim que se passa com a forma sonata. Iniciada a "ação musical", tudo o que acontece é ditado por esse princípio de causalidade que confere coerência dramática à forma. Uma infor- 
mação nova só faz sentido em relação à informação apresentada anteriormente. Ao contrário do que muitos pensam, isso não se constitui numa diminuição de liberdade para o compositor; a forma musical não é uma "fórmula", muito pelo contrário, haja vista a imensa variedade de peças musicais desenvolvidas pelos compositores em forma sonata. A forma apenas estabelece um princípio organizacional que torna o compositor muito mais responsável por toda a informaçào musical por ele apresentada no decorrer da peça. A forma exige do compositor coerência narrativa e dramática. $\mathrm{O}$ grau de restrição aqui é o mesmo que para qualquer outro criador, especialmente o escritor, ou o dramaturgo, que também estão limitados ao material que eles mesmos selecionaram para desenvolver o seu romance ou drama. Todo o trabalho necessário para fazer do material contido nessa estrutura uma obra de arte é de inteira responsabilidade da criatividade do artista. A forma não faz a arte, assim como o artista criativo não faz da forma uma prisão para a sua criatividade. Em suma: forma nào é fôrma!

\section{III - Desenvolvimento: Análise}

\section{SONATA EM DÓ MAIOR - KV 309 - W. A. MOZART}

$1^{\circ}$ Movimento: Allegro con Spirito

\section{1) Primeiro Grupo Temático}

Este é um movimento em forma sonata que não possui introdução. Mozart inicia a peça apresentando de imediato o primeiro grupo temático, que ocupa os compassos de número 1 a 20 , tendo sua conclusão no primeiro tempo do compasso 21 . 

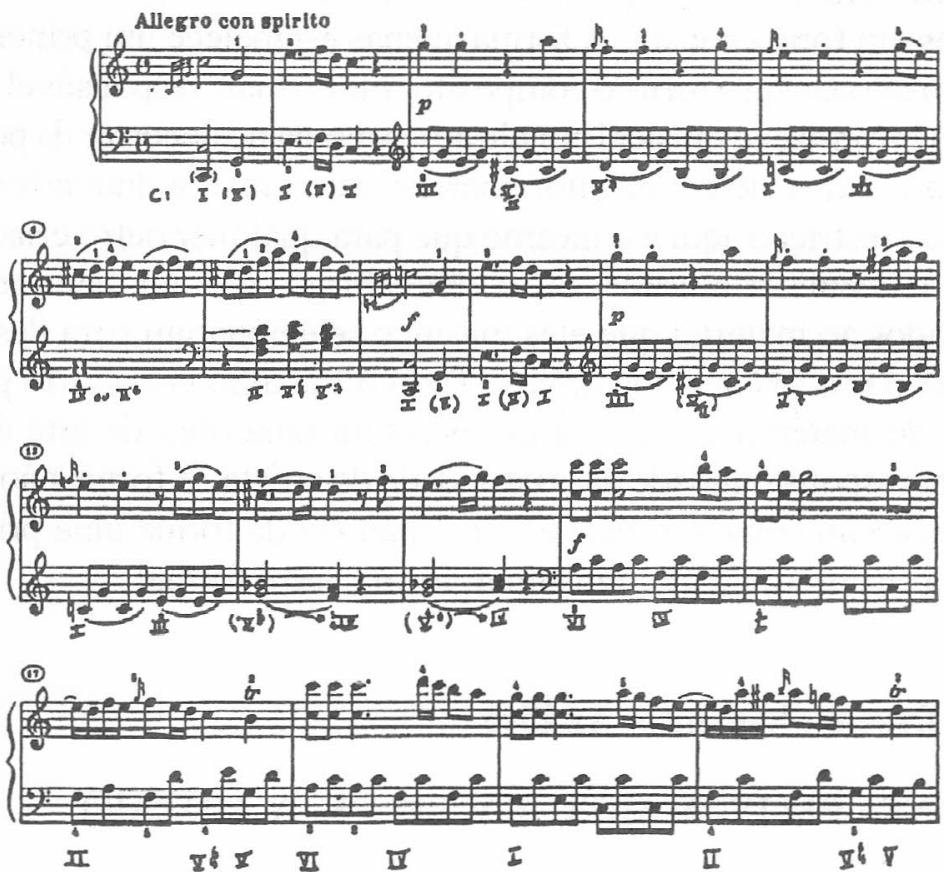
Como podemos notar, Mozart inicia a apresentação do primeiro grupo temático com uma frase composta por dois motivos. É uma frase de caráter afirmativo que é reforçado pela distribuição em oitavas. Embora não haja acorde, sente-se claramente o movimento cadencial sobre Dó maior, tonalidade principal da peça e sobre a qual será construída toda esta seçào.

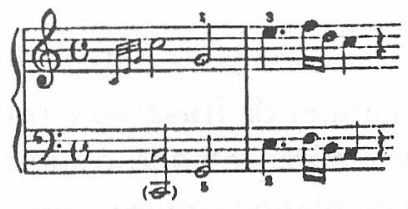

Na verdade, não temos aí dois motivos propriamente ditos, mas um único motivo modificado em sua repetição:

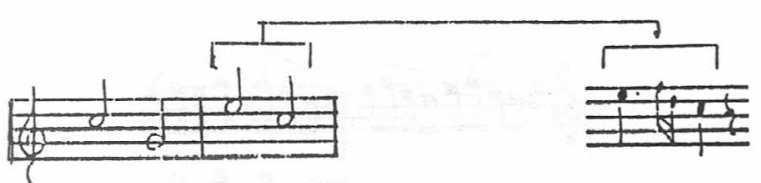

A exposição prossegue com a introduçào de uma nova idéia que é apresentada numa frase de três compassos:

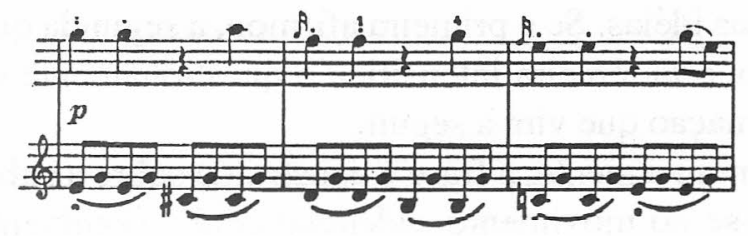


Sobre um "baixo de Alberti" em colcheias, Mozart constrói a frase com um único motivo em estrutura seqüencial. Harmonicamente, a frase permanece ainda restrita ao campo de Dó Maior, porém, já podemos detectar um primeiro cromatismo: a nota Dó sustenido no compasso de número 3 . Este cromatismo resulta harmonicamente num acorde de Lá com sétima (A7), ou seja, uma dominante secundária, mais especificamente a dominante do segundo grau, Ré menor (Dm), sem contudo resolver sobre tal acorde.

Nesta frase, o contraste já é estabelecido tanto pela dinâmica (piano), como pelo caráter da frase: se a primeira frase havia sido de caráter afirmativo, apresentando o motivo inicial em oitavas, aqui Mozart separa os planos sonoros, um, pulsante e harmônico (baixo de Alberti) e outro, melódico. Ouvindo atentamente, podemos notar como esta segunda frase rompe com a conclusividade da primeira.

Ritmicamente, Mozart faz uma progressão crescente de movimento na melodia, que vai continuar na próxima frase:

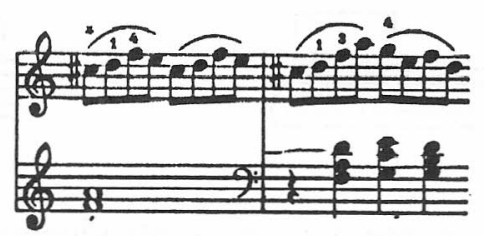

O motivo da primeira frase foi construido sobre as mínimas, o da segunda sobre semínimas, e o desta terceira em colcheias.

Esta terceira frase serve, ao mesmo tempo, como uma resposta ao conflito das duas primeiras e como caminho para a conclusão dessas duas idéias. Se a primeira afirmou, a segunda questionou a afirmação, esta terceira intensifica o questionamente e prepara a nova afirmaçào que virá a seguir.

Harmonicamente, a frase é construída sobre a subdominante e conclui-se no movimento cadencial com a dominante quarta e 
sexta $\left(V^{6}{ }_{4}\right)$, dominante com sétima (V7), que vai conduzir à tônica do próximo compasso. O cromatismo que havia sido apresentado na segunda frase permanece (Dó ${ }^{\prime}$ ) como apojatura da nota Ré ou, dependendo da interpretação, como quinta aumentada da subdominante.

Concluída esta primeira idéia, Mozart vai reexpô-la com pequenas modificações. A primeira e a segunda frases aparecem praticamente iguais:

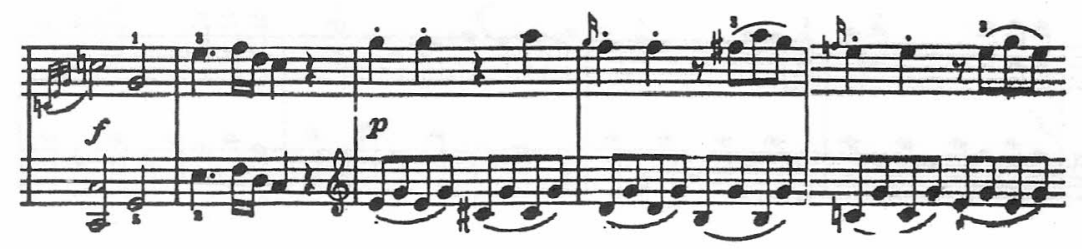

No lugar da terceira frase, Mozart substitui a linha melódica de colcheias por um motivo que sintetiza a idéia da primeira frase e aquele motivo em colcheias da terceira:

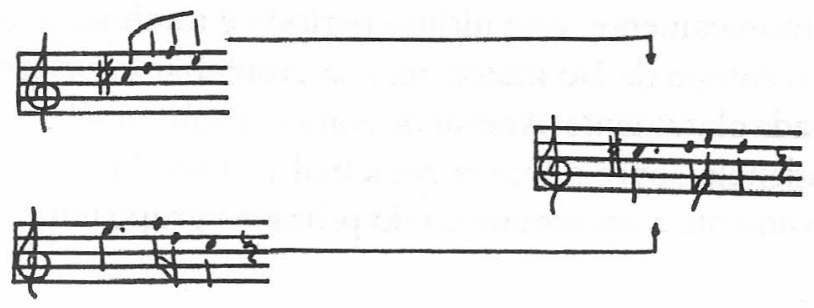

Harmonicamente, há também uma modificaçào que ocorre pela inclusão de um acorde diminuto que cadencia sobre as subdominantes (II e IV). A frase completa aparece assim:

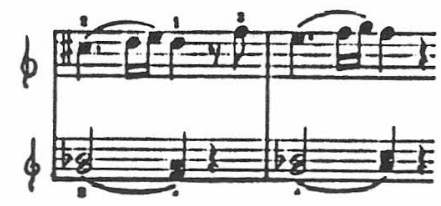


Essa repetição do período inicial serve para reforçar o material temático do primeiro grupo, pois na forma sonata não é possível o entendimento da peça como um todo se nào houver uma total clareza desse material temático para o ouvinte.

A seguir, Mozart encerra o primeiro grupo temático com uma frase de três compassos que se repete com pequenas modificações. Esta frase é composta por fragmentos de todo o material temático apresentado até então:
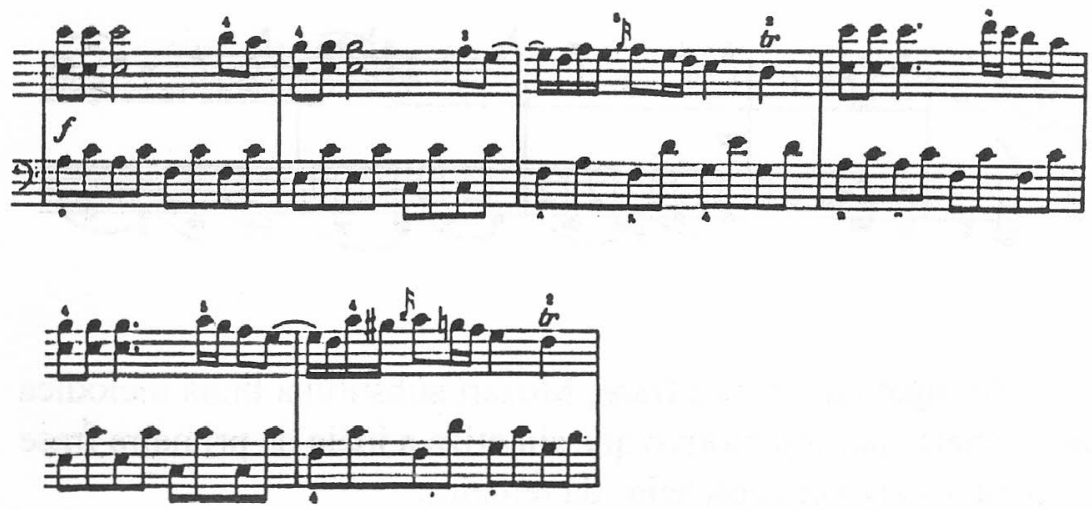

Harmonicamente, este último periodo é totalmente construído sobre o campo de Dó maior; não há cromatismo e a tonalidade é reafirmada claramente. Apesar de começar sobre a relativa menor (Am), cadencia sobre a tônica principal (C) no final, encerrando conclusivamente a apresentação do primeiro grupo temático.

2) Ponte

Sobre os compassos de numero 21 a 32, Mozart constrói a ponte, que liga os grupos temáticos 1 e 2 : 

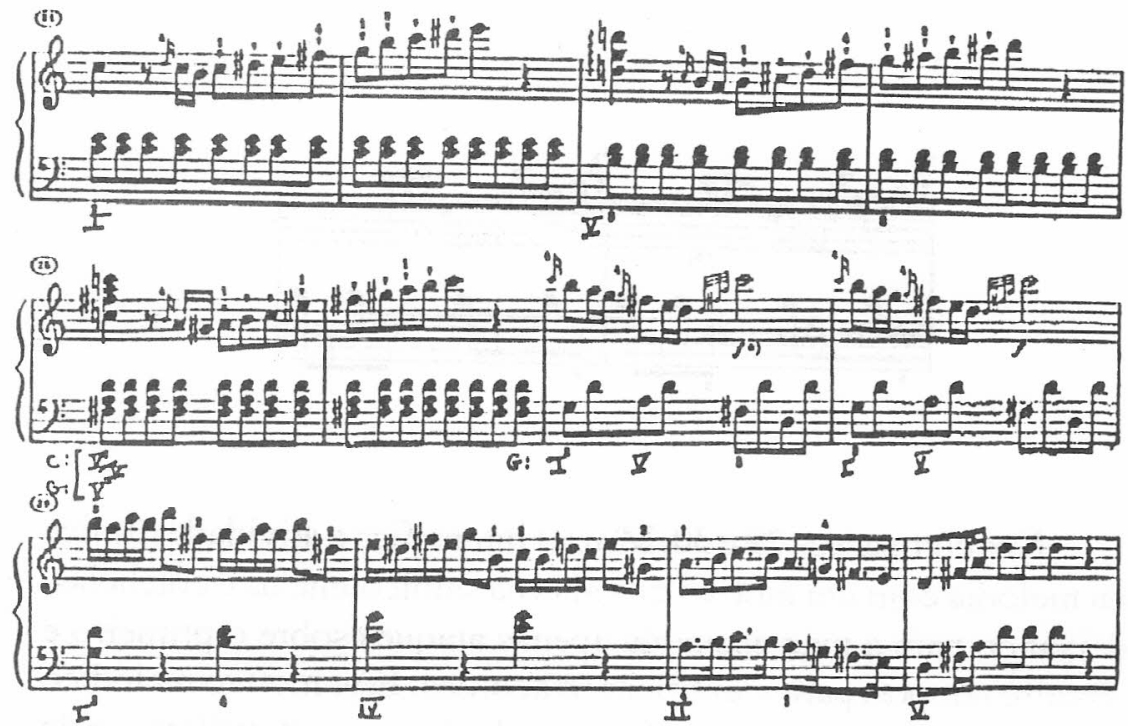

A ponte inicia-se com uma frase de dois compassos. Sobre o acorde de tônica, que pulsa em colcheias, Mozart constrói uma estrutura melódica ascendente rica em cromatismos. Estes cromatismos fazem com que o ouvinte já sinta o clima de instabilidade que precede a modulação para a tonalidade da dominante $(G)$, onde será apresentado o segundo grupo temático.

A mesma frase se repete mais duas vezes: a primeira sobre o acorde de dominante $(\mathrm{G})$, e a segunda sobre o acorde de dominante da dominante (D7), que é também o acorde de dominante de Sol maior, para onde a modulação está sendo conduzida. Melodicamente esta última repetição mantém os cromatismos das duas anteriores.

Com isso, Mozart chega à tonalidade de Sol maior e vai cadenciar para confirmar esta nova tonalidade. Nos dois compassos seguintes (27-28), temos um único motivo melódico sobre um baixo de Alberti que reafirma tônica e dominante de Sol maior. $\mathrm{O}$ compasso 28 é uma repetição literal do anterior. 


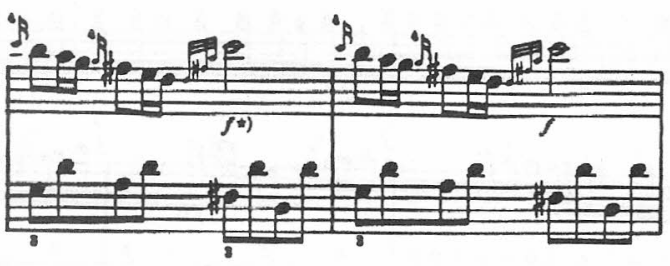

Nos compassos 29 e 30, Mozart intensifica a atividade rítmica da melodia com um motivo que alterna semicolcheias e colcheias, deixando para a mão esquerda apenas ataques sobre o primeiro e terceiro tempos, para identificar os acordes. Este motivo melódico se repete seqüencialmente. Neste trecho há uma intensificação da tensào interna da ponte, que se conclui nos compassos 31 e 32 com uma linha por oitavas que resolve sobre a dominante (D).

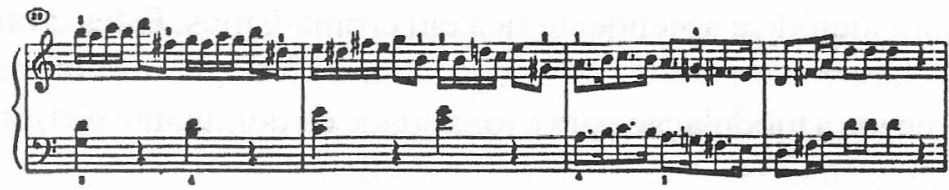

Pensando em termos da estrutura dramática da sonata, esta ponte cria um momento de instabilidade dada a grande quantidade de cromatismos e a progressão harmónica modulante. O final da ponte, na dominante, serve como "deixa" para o segundo grupo temático. Após a instabilidade, cria-se uma nova estabilidade em outro campo, onde será apresentada uma nova idéia.

3) Segundo Grupo Temático

O segundo grupo temático ocupa os compassos de número 33 a 58: 

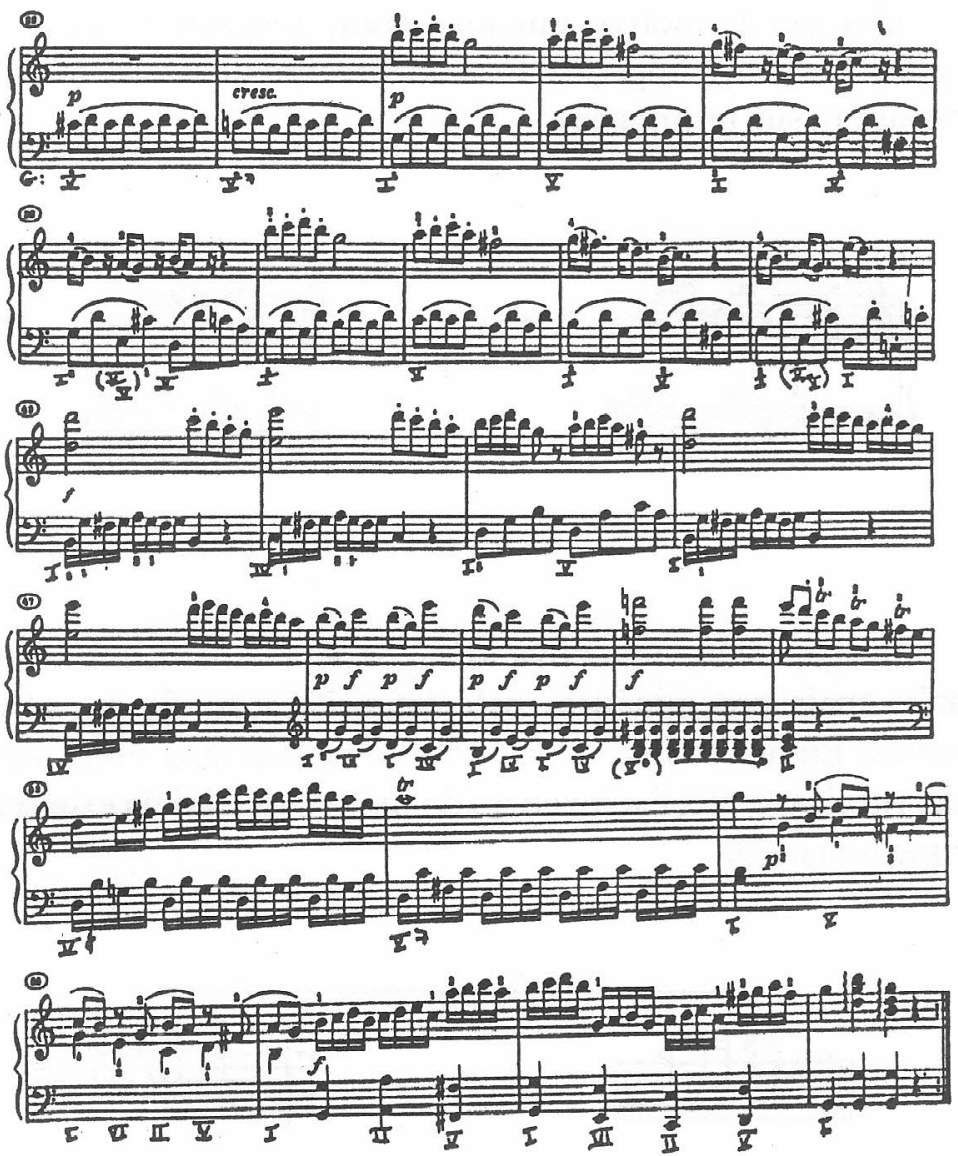

Mozart inicia esta seção com una introdução de dois compassos, apenas na mão esquerda. Nos compassos seguintes, sobre um baixo de Alberti, é apresentada uma linha melódica construída sobre dois motivos:
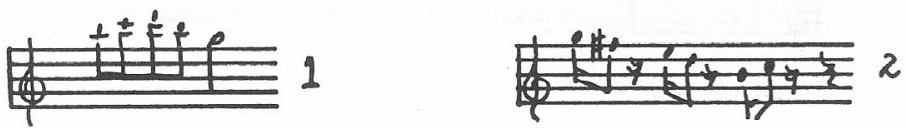
O segundo motivo funciona como resposta ao primeiro. A seguir, a idéia é repetida exatamente igual, sendo modificada apenas em sua terminação:
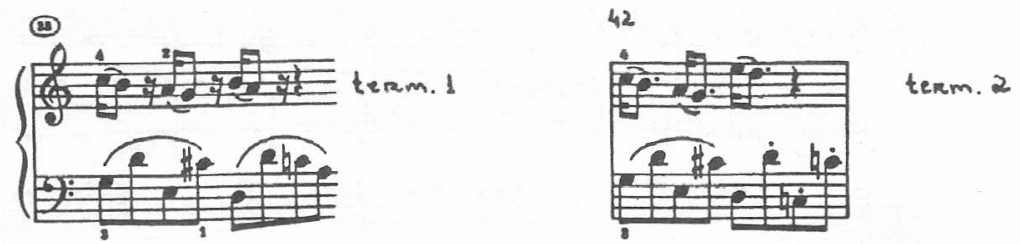

Surge, então, uma nova idéia, onde a linha da mão esquerda ganha mais proeminência pela intensificação de sua atividade rítmica. Enquanto isso, a mão direita realiza uma linha melódica que, ritmicamente, é a inversão do motivo que inicia este segundo grupo temático:

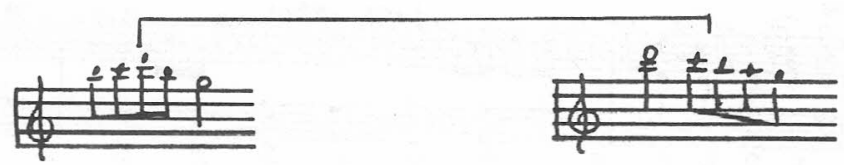

No compasso 45, Mozart repete a idéia do primeiro motivo com valores mais curtos:

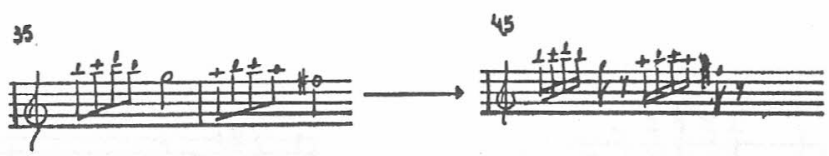


Esta idéia vai sendo trabalhada até o compasso 47. No compasso 48 é introduzido um novo material, que conduz à conclusão do segundo grupo temático. Aqui, Mozart une elementos apresentados durante a seção:
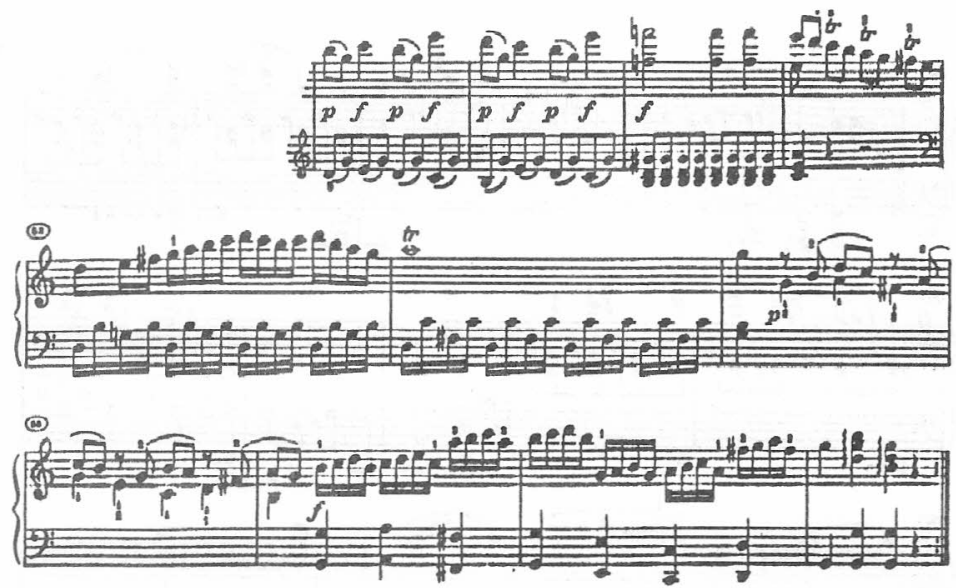

Toda a condução para o encerramento da seção é feita sobre o motivo inicial tratado seqüencialmente nos compassos 56 e 57.

Harmonicamente, todo o segundo grupo temático é construído sobre o campo de Sol maior. Não são encontrados cromatismos. $O$ único acorde fora do campo é o acorde de Sol sustenido diminuto $\left(\mathrm{G}^{\# \mathrm{O}}\right)$, que funciona como dominante da subdominante relativa (Am), no compasso 50.

Este segundo grupo temático contrasta com o primeiro não apenas no que diz respeito à tonalidade, mas também quanto à atividade rítmica e ao caráter: o segundo grupo é mais uniforme que o primeiro, pois é construído basicamente sobre uma única idéia (motivo inicial), enquanto que o primeiro apresenta uma variedade interna muito maior, en todos os aspectos.

Tendo concluída a exposiçào, encontramos um ritornello, que era um procedimento obrigatório no período clássico. Hoje, muitos intérpretes já não o realizan. Isto se deve ao fato de que, com o passar do tempo, o ouvinte se torna mais habituado a forma, não sendo mais necessário um número tão grande de reiterações. 
4) Desenvolvimento

Tem início, então, o desenvolvimento, que ocupa os compassos de número 59 a 93 :
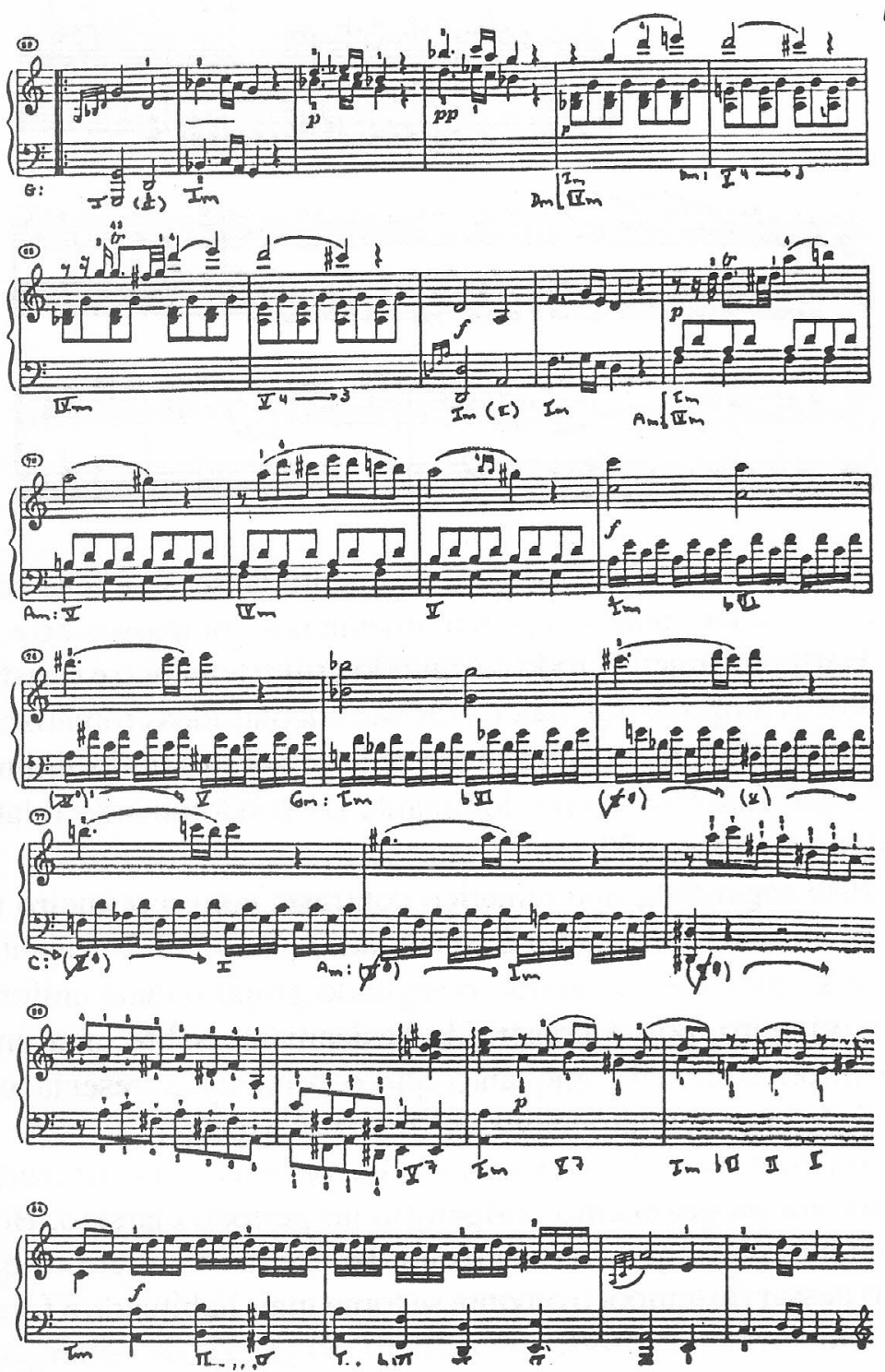

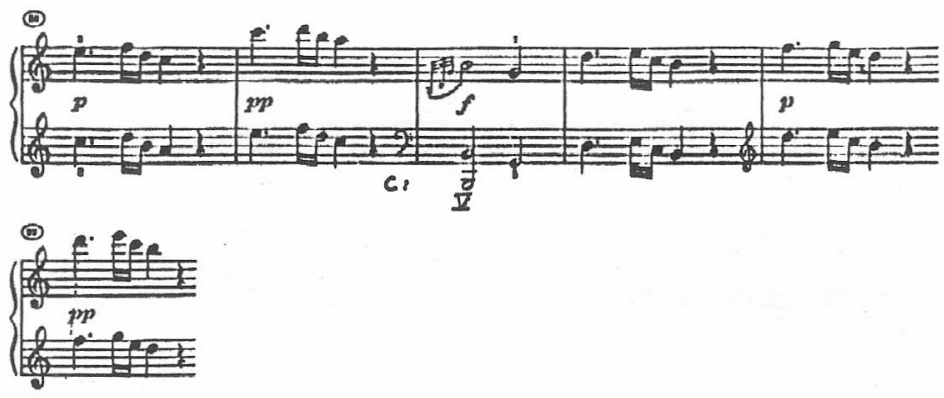

Mozart começa o desenvolvimento provocando, de imediato, uma surpresa: no primeiro compasso, apresenta o motivo inicial do primeiro grupo temático, agora sobre o campo de Sol. Contudo, percebemos que não estamos mais sobre um acorde de Sol maior. Há uma inversão modal e a frase continua em Sol menor. A partir de então, vamos transitar por vários campos tonais.

Sobre o acorde de Sol menor estào os cinco compassos iniciais. Os quatro primeiros formam uma frase completa, construída sobre o motivo do primeiro grupo temático.

No quinto compasso (63) tem início uma nova idéia. O acorde de Sol menor é seguido por um acorde de dominante: Lá com sétima e quarta suspensa que resolve na terça. Estes dois compassos (63 e 64) se repetem, tendo como única modificação uma ornamentação melódica (65 e 66). A progressão Gm - A7 nos remete à tonalidade de Ré menor. De fato, chegamos ao acorde de Ré menor (Dm) no compasso 67, onde temos novamente aquele motivo do primeiro grupo temático. Seqüencialmente, Mozart apresenta a mesma idéia apresentada sobre Sol menor e, assim, o acorde de Ré menor ( $\mathrm{Dm}$ ) é sucedido por un de Mi com sétima (E7 4-3), que nos remete para Lá menor.

Mozart continua trabalhando sobre o mesmo motivo do primeiro grupo temático. No compasso 73 ele é modificado em suas relações intervalares, mas permanece exato ritmicamente. Neste mesmo compasso ocorre uma uniào desta idéia oriunda do primeiro grupo temático com uma outra do segundo: o baixo de Alberti por semicolcheias. 


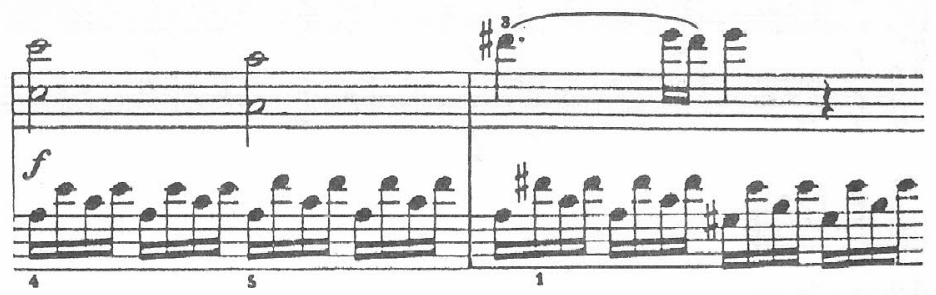

Os compassos 75 e 76 são uma repetiçao seqüencial dos dois anteriores, com uma transição brusca para o acorde de sol menor:

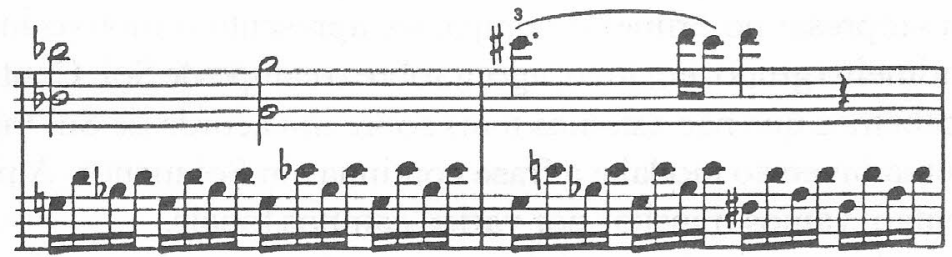

E Mozart conclui este período com o mesmo motivo, seqüencialmente, por mais dois compassos:

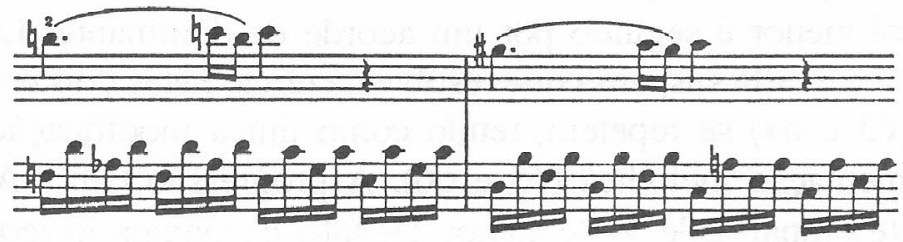

Aí vamos encontrar uma pequena transiçào construida sobre o acorde de Ré sustenido diminuto $\left(\mathrm{D}^{\#()}\right)$, resolvendo no terceiro tempo do compasso 81 sobre o acorde de Mi com sétima (E7), remetendo-nos novamente a Lá menor:

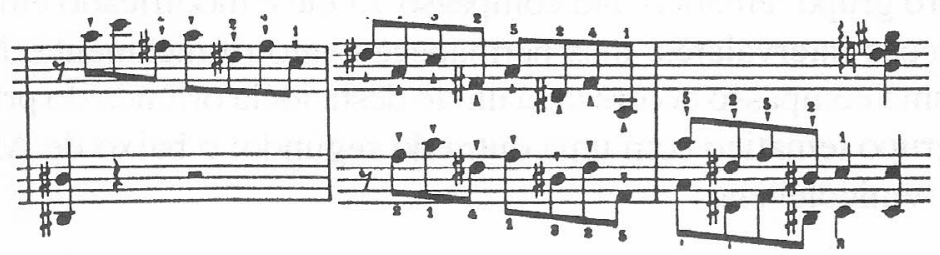


Em Lá menor começa, entào, a ser trabalhado o material do segundo grupo temático. Nos compassos de número 82 a 85 sào apresentados dois motivos desse grupo:

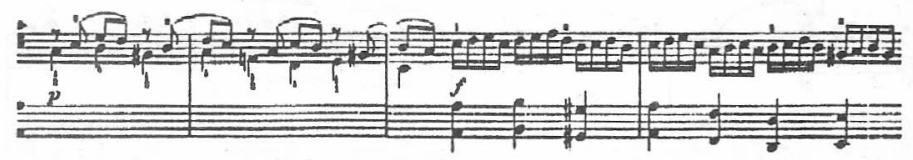

Sobre Lá menor, Mozart retoma aquele motivo do primeiro grupo temático. Em duas frases de quatro compassos reconduz o movimento harmônico em direçào a Dó maior, terminando o desenvolvimento sobre a dominante (G7) dessa tonalidade.

É interessante notar que, por todo o desenvolvimento, há uma grande ênfase nos modos menores, contrastando com as outras seções da peça, que são construídas sempre em modo maior.

5) Reexposiçăo

A reexposição tem início no compasso 94 e dura até o compasso 151:
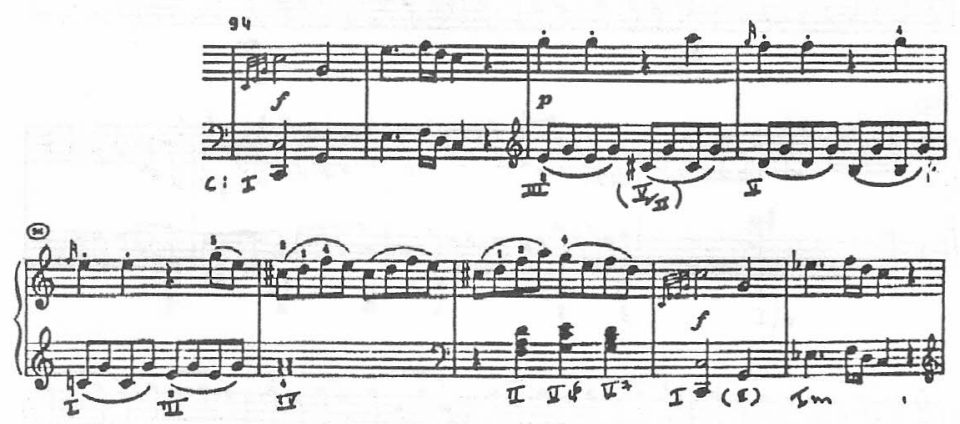

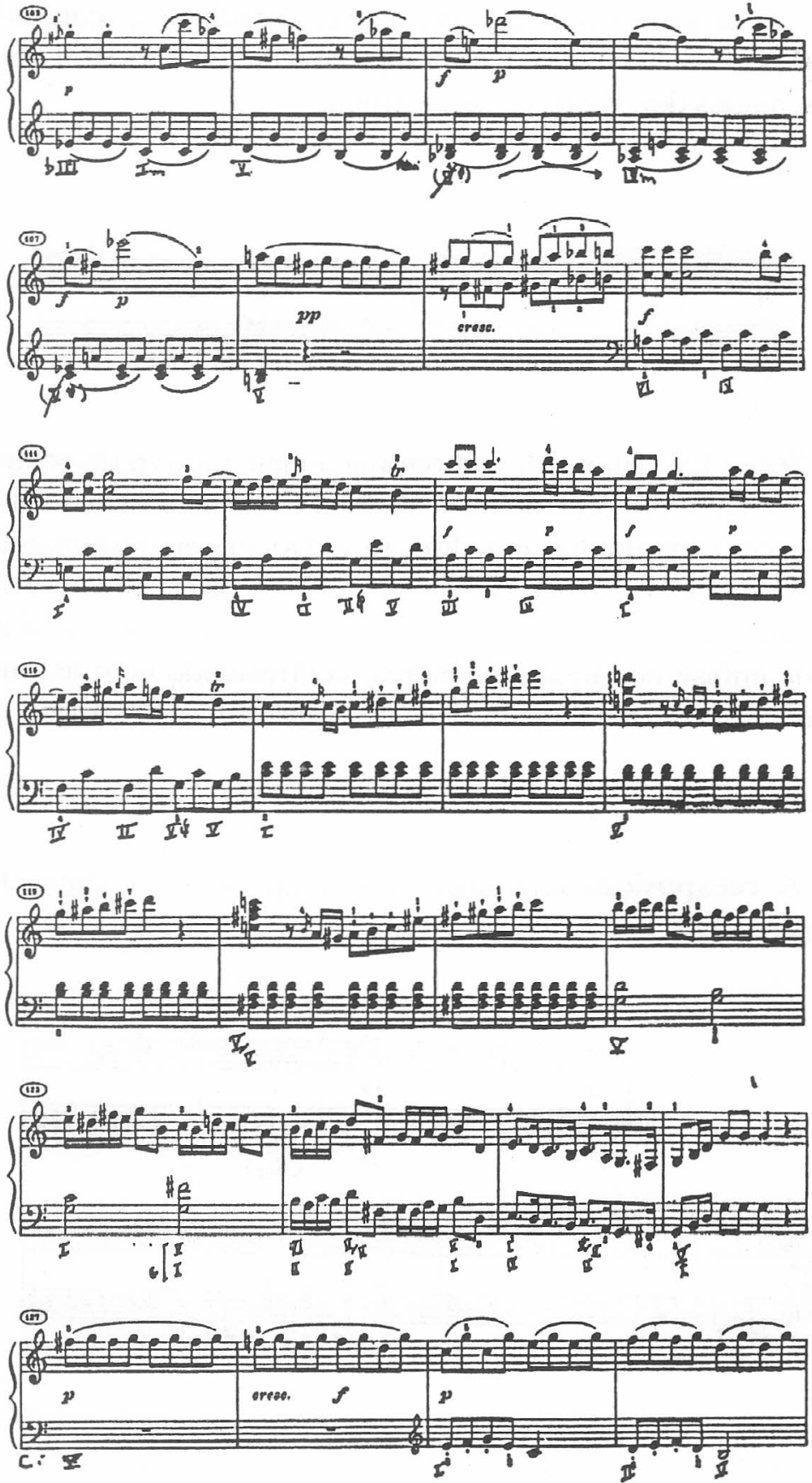

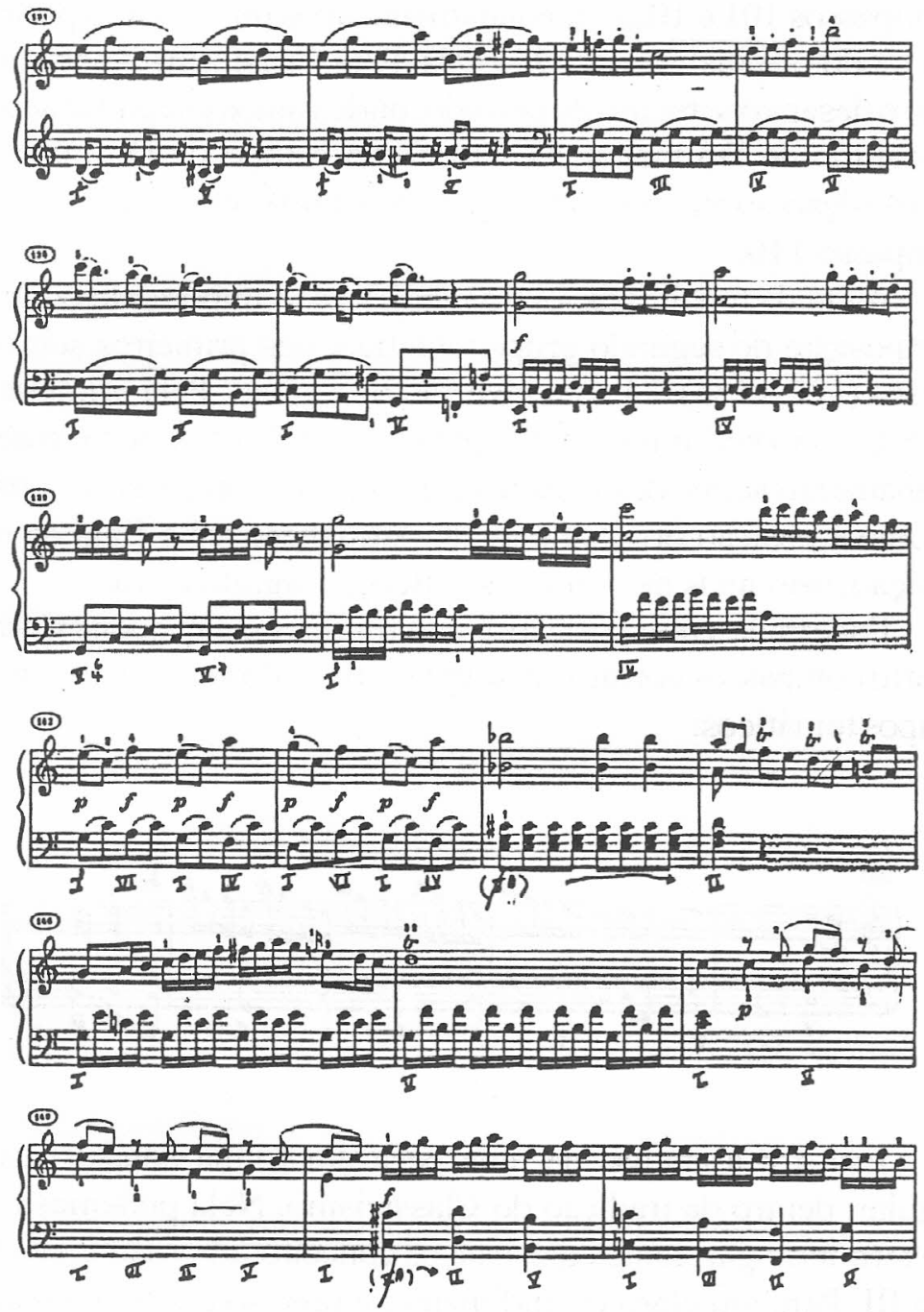
Como podemos notar, o primeiro tema já não aparece exatamente igual à exposição. Tal como vimos no item III, ele foi transformado pelo desenvolvimento. Esta modificação diz respeito ao modo: no desenvolvimento, o motivo inicial é trabalhado em modo menor e é assim que ele torna a aparecer na reexposição (compassos 101 e 102), imediatamente após ter sido reexposto em seu modo original, maior (94 e 95). Esta transformação vai afetar todo o desenvolvimento do período, onde vamos encontrar acordes do campo de Dó menor. O retorno ao campo de Dó maior e à reexposição exata do primeiro grupo temático só acontece no compasso 110.

Além da tonalidade, outra modificaçào importante ocorre na reexposição do segundo grupo temático: nos primeiros seis compassos (127 a 132), há uma inversão de regiòes. Pela primeira vez na peça, o material melódico aparece na mão esquerda e o acompanhamento acima deste, na mão direita. No compasso 133 há um retorno à posição original e assim permanece até o final da reexposição, sem mais nenhuma modificaçào significativa.

Encerrada a reexposiçào, encontramos uma pequena Coda de quatro compassos construída sobre motivos do primeiro e segundo grupos temáticos:

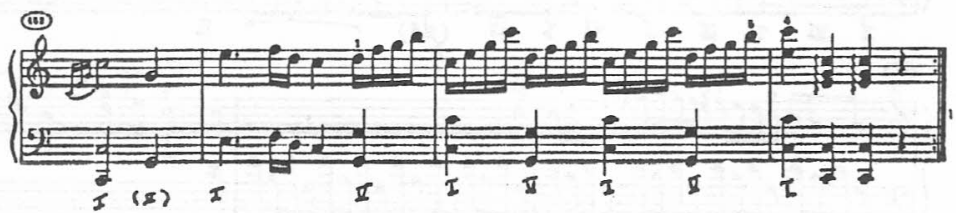

Esta foi a análise de uma peça em forma sonata bastante regular, dentro da tradiçào do Classicismo. Nela pudemos tratar, em terminologia técnica musical, os conceitos abordados nos itens II e III. Para um claro entendimento, é preciso ouvir atentamente esta e outras peças em forma sonata, para que se reconheça auditivamente o processo narrativo e dramático da forma. 


\section{IV - Reexposição: Considerações Finais}

A música é, por um lado, uma linguagem simples, pois trabalha com um número bastante limitado de elementos básicos: doze alturas, sete figuras de valor básicas e alguns outros poucos elementos, como articulações e dinâmicas. Por um outro lado, ela é uma linguagem bastante complexa, dada a infinidade de combinações possíveis destes elementos básicos. Neste ponto, a música é muito similar à matemática, que constrói todo o seu modo de expressão a partir de dez algarismos e quatro operações básicas.

Isso faz com que a música possua uma série de especificidades que a tornam uma linguagem passivel de abordagens as mais diversas, tendo como ponto de partida as mais inusitadas premissas. Já tentaram relacionar os sons musicais com as cores do arco-íris, com os astros e tantas outras coisas... Algumas dessas tentativas são legítimas, outras não, mas de fato, muito pouco contribuíram, seja para o trabalho do músico enquanto profissional, seja para o estudioso da música, realmente preocupado em responder algumas questões intrigantes sobre essa linguagem tão peculiar.

A música e o drama ou as linguagens narrativas como um todo possuem uma série de similaridades e, através do que já foi dito sobre uma ou outra delas, podemos encontrar respostas para algumas das questões que a musicologia ainda nào esclareceu. A dramaturgia e o estudo da narrativa, aplicados à linguagem musical, produzem, de fato, um novo enfoque, capaz de contribuir efetivamente para o trabalho daqueles que produzem música: compositores, intérpretes, regentes, produtores, e de todas as atividades afins.

\section{V - Coda}

\section{A. Índice de Citações}

1) ARISTÓTELES, Arte Poética, p. 293.

2) A. ROSENFELD, O Teatro Épico, p. 15. 
3) ARISTÓTELES, op. cit., p. 298.

4) A. ROSENFELD, op. cit., p. 16.

5) ARISTÓTELES, op. cit., p. 310.

6) R. PALLOTTINI, Introdução d̀ Dramaturgia, p. 19.

7) Idem, ibidem, pp. 19-20.

8) M. ESSLIN, Uma Anatomia do Drama, p. 47.

9) Idem, ibidem, pp. 48-49.

10) H. CAPUZZO, Twilight Zone - Combinatórias Narrativas e Intertextualidades, p. 14.

11) M. ESSLIN, op. cit., p. 49.

12) Idem, ibidem, p. 49-51 (Gráficos por arcos).

13) ARISTÓTELES, op. cit., p. 315.

14) A. ROSENFELD, op. cit., p. 30.

B - Bibliografia

\section{FORMA SONATA}

CANDÉ, Roland de. História Universal de la Música. Madrid, Aguilar, 1981. KOHS, Ellis B. Musical Form. Boston, Houghton Mifflin Co., s/d.

PISK, Paul \& ULRICH, Homer. A History of Music and Music Style. New York, Harcourt, Brace \& World Inc., 1963.

SCHOENBERG, Arnold. Fundamentos da Composição Musical. São Paulo, Edusp, 1991.

WISNIK, José Miguel. O Som e o Sentido. São Paulo, Companhia das Letras, 1990.

\section{DRAMATURGIA}

ARISTÓTELES, Arte Retórica e Arte Poética. Rio de Janciro, Tecnoprint, s/d. CAPUZZO, Heitor. Twilight Zone - Combinatórias Narrativas e Intertextualidades. Dissertação de Mestrado. São Paulo, ECA-USP, 1988.

ESSLIN, Martin. Uma Anatomia do Drama. Rio de Janciro, Zahar, 1977.

PALlotTINI, Renata. Introdução à Dramaturgia. São Paulo, Brasiliense, 1983.

ROSENFELD, Anatol. O Teutro Épico. São Paulo, Purspectiva, 1985.

Claudiney Rodrigues Carrasco é Professor no Instituto de Artes da UNICAMP e pós-graduando na ECA-USP. 